CSDM Views 6

\title{
Defence transformation outlook in the resource framework of the 2010 White Paper
}

Georgi Tsvetkov

Sofia, 2012 
Rigorous comparison of ambitions stated in Bulgaria's 2010 defence white paper and the respective resource framework, taking shape till then, puts in doubt the prospects for transformation of the country's armed forces.

Keywords: Defence capability, defence expenditure, level of ambition, comparative analysis

\section{Георги Цветков, Перспективи пред трансформацията в ресурсната рамка на Бялата книга за отбраната и ВC}

Сравнителният анализ на равнището на амбиции, заявено в Бялата книга за отбраната и въоръжените сили на Република България от 2010 г., и съответната ресурсна рамка, фрормирана чрез последващи правителствени и парламентарни решения, поставя под съмнение перспективите пред трансформацията на отбраната.

Ключови думи: Отбранителни способности, разходи за отбрана, равнище на амбиция, сравнителен анализ

Editors: Todor Tagarev, Velizar Shalamanov, Venelin Georgiev, Valeri Ratchev 
The new White Paper on Defence of the Republic of Bulgaria of 2010 should provide guidance for the future development of Bulgarian Armed Forces, at least by 2020. The intentions of the current Bulgarian government are relatively clear, but there are some problems in key areas, as follows:

1. The reduction in defence expenditure is explained with the financial crisis. The impact of defence transformation, however, is going to be seen once the crisis is left behind. Current financing problems cannot be the reason for overall defence transformation.

2. Such transformation would mean a strategic reassessment of national defence. All evaluations of the environment, stated in the White Paper, with the resulting military requirements, only repeat the analysis from the previous White Paper of 2002, as well as the lower-level analysis which has been made since then. Therefore the reasons for an overall change of vision as to the place of armed forces lie elsewhere.

3. As of 1998 (the beginning of the actual armed forces' transformation) there has been one predominating motive - the number of the military personnel is shrinking and the structure is optimized so as the resources needed for the overall rearmament to be made available. At present, along with the shrinking personnel numbers, defence expenditures are also shrinking. It is not clear if the necessary rearmament is going to be financially provided for. Without it, the Bulgarian armed forces cannot be adequate to the contemporary conditions.

4. The parameters for the future level of financing pointed out in the White Paper have not been confirmed by the government. On the contrary, there have been indications that the Council of Ministers (and, consequently, the Parliament) is likely to allocate fewer funds to defence.

5. There are fears that, for the first time since 1998, the armed forces are not given the task to develop their capabilities; i.e. it can be presupposed that they will not be able to protect national interests effectively, but at least they are going to require fewer maintenance resources.

\section{Defence Expenditures Total}

The capabilities of Bulgarian Armed Forces should be significantly enhanced in the next years in order to achieve relevant interoperability with NATO allies and to contribute more successfully to allied crisis response, stabilization operations and the regional security. Such deep transformation should include complete rearmament of the Armed Forces, which would require significant resources for a long period of time (by 2025). If, however, Bulgaria wants to have modern military forces in the middle of the next decade, the first steps in a major defence investment program should be made in the next few years. Bulgarian economy could provide the required resources, but it seems that the Bulgarian government has different priorities as to the allocation of resources.

The calculations below are based on the three-year budget forecast for the period 20112013, made by the Ministry of Finances and approved by the Council of Ministers. The figures for 2014 are based on "reasonable" assumptions. 


\begin{tabular}{|c|c|c|c|c|c|}
\hline & 2011 & 2012 & 2013 & 2014 & $\begin{array}{c}\text { Total for the } \\
\text { period }\end{array}$ \\
\hline GDP/mil BGN/ & 73181 & 78716 & 84354 & $\sim 90000$ & \\
\hline Estimated def. budget ${ }^{1} / \mathrm{mil} \mathrm{BGN} /$ & 990,630 & 990,630 & 990,630 & 990,630 & \\
\hline Investment costs ${ }^{2} / \mathrm{mil}$ BGN/ & 148,950 & 148,950 & 148,950 & 148,950 & 595,80 \\
\hline $1,5 \%$ of GDP for def. expenditure & 1097 & 1180 & 1256 & 1350 & \\
\hline Investment costs ${ }^{3} / \mathrm{mil}$ BGN/ & 164,55 & 177 & 188,4 & 201,5 & 732,45 \\
\hline $2 \%$ of GDP for def. expenditure & 1464 & 1574 & 1687 & 1800 & \\
\hline Investment costs ${ }^{4} / \mathrm{mil}^{\mathrm{BGN}} /$ & 365,9 & 393,58 & 421,77 & 450 & 1631,25 \\
\hline Investment costs ${ }^{5} / \mathrm{mil}$ BGN/ & 530,45 & 570,5 & 610,17 & 652,5 & 2365,62 \\
\hline
\end{tabular}

For comparison, data about the period 2003-2009 is provided below, based on the annual reports for budgetary implementation.

\begin{tabular}{|l|c|c|c|c|c|}
\hline & $\begin{array}{c}\text { GDP } \\
\text { /mil BGN/ }\end{array}$ & $\begin{array}{c}\text { Budget of } \\
\text { MoD } \\
\text { /mil BGN/ }\end{array}$ & $\begin{array}{c}\text { Def. budget } \\
\text { as \% of GDP }\end{array}$ & $\begin{array}{c}\text { Investment } \\
\text { costs } \\
\text { /mil BGN/ }\end{array}$ & $\begin{array}{c}\text { Investment costs } \\
\text { as \% of def. } \\
\text { budget }\end{array}$ \\
\hline 2003 & 34628 & 1001 & $2,89 \%$ & 126,6 & $12,6 \%$ \\
\hline 2004 & 38823 & 978 & $2,52 \%$ & 173,7 & $17,8 \%$ \\
\hline 2005 & 42797 & 1051 & $2,45 \%$ & 216,7 & $20,6 \%$ \\
\hline 2006 & 49360 & 1116 & $2,26 \%$ & 245,5 & $22 \%$ \\
\hline 2007 & 56519 & 1414 & $2,6 \%$ & 397,6 & $28,1 \%$ \\
\hline 2008 & 66728 & 1553 & $2,33 \%$ & 468,7 & $30,2 \%$ \\
\hline 2009 & 66256 & 1273 & $1,92 \%$ & 292,8 & $23 \%$ \\
\hline Total & & & & 1921,6 & \\
\hline
\end{tabular}

A quick comparison shows that the foreseen investment level is in practice lower than the one during the previous transformation stage. Even the assumptions about the level of defence expenditure in the White Paper will probably not be adequate for the implementation of the major rearmament program needed. The Bulgarian government has in fact not even committed to the level of financing foreseen in the White Paper on Defence. This in practice means that it would be impossible to achieve the goals set in the White Paper.

\section{Defence expenditure on military personnel}

One of the most important elements both in previous and in the current Bulgarian defence transformation stage have been the restructuring and reduction in number of the Armed Forces personnel. Main goal of these two processes is to increase efficiency and allocation of more funds for investments.

\footnotetext{
1 Three- year budget prognosis for the period 2011-2013 (www.minfin.bg/document/8444:1). In fact, in the estimated budget for 2011 investment costs amount to BGN 100 mil.

$215 \%$ of the MoD budget.

$315 \%$ of the MoD budget.

$4 \quad 0.5 \%$ of GDP for defence investments from the budget of the government.

$515 \%$ of the MoD budget (1.5\% of GDP) $+0.5 \%$ of GDP for defence investments.
} 


\begin{tabular}{|l|c|c|}
\hline & $2009^{6}$ & $2014^{7}$ \\
\hline Armed Forces Personnel & 44100 & 37000 \\
\hline Armed Forces Active Military Personnel & 34700 & 27000 \\
\hline Armed Forces Reserve Military Personnel & - & 3000 \\
\hline Active Military Personnel of the Bulgarian Army & 30400 & $\sim 23500$ \\
\hline Reserve Military Personnel of the Bulgarian Army & - & 2700 \\
\hline
\end{tabular}

One of the main indicators of the armed forces' capabilities is the costs per individual soldier. ${ }^{8}$ In the case of Bulgaria, armed forces transformation is directly linked to a significant increase of expenditure per soldier since its current level is one of the lowest in NATO. The White Paper foresees that the budget for defence would be 1,5\% of GDP. This would result in an increase of expenditure per soldier as compared with the previous period. It is, however, doubtful whether this would lead to a real transformation of Bulgaria's defence capabilities. When we take into consideration the government's decisions as to the allocation of state financing, one can conclude that the level of expenditure per soldier will not increase.

\begin{tabular}{|l|c|c|c|}
\hline \multirow{2}{*}{} & \multicolumn{3}{|c|}{ Expenditure per soldier in BGN/EUR } \\
\cline { 2 - 4 } & $\begin{array}{c}\text { Armed Forces } \\
\text { Personnel }\end{array}$ & $\begin{array}{c}\text { Armed Forces Active } \\
\text { Military Personnel }\end{array}$ & $\begin{array}{c}\text { Active Military Personnel of } \\
\text { the Bulgarian Army }\end{array}$ \\
\hline Budget 2009 & $\sim 28900 / \sim 14700$ & $\sim 36700 / \sim 18700$ & $\sim 41900 / \sim 21400$ \\
\hline BGN 990 630 mil & $\sim 26800 / \sim 13700$ & $\sim 36700^{9} / \sim 18700$ & $\sim 42150^{10} / 21500$ \\
\hline $1,5 \%$ of GDP & $\sim 34200 / \sim 17450$ & $\sim 46850^{11} / \sim 23900$ & $\sim 53800^{12} / \sim 27450$ \\
\hline $2 \%$ of GDP & $\sim 45700 / \sim 23300$ & $\sim 62600^{13} / \sim 31900$ & $\sim 71900^{14} / \sim 36700$ \\
\hline
\end{tabular}

\section{Findings about the Future of Bulgaria's Defence Transformation}

To enhance significantly Bulgaria's defence capabilities, a number of major investment projects have to be implemented:

- Simple calculations show that the purchasing and putting into service of 10-14 contemporary multi-role fighters would cost more than BGN 1- 1,5 bn.

- The issue with the helicopters of the Air Forces is still pending. In exchange for BGN 300 mil. the Bulgarian Army received 12 Cougar helicopters that have to be equipped additionally in order to be able to be used in military operations against paramilitary forces. The fate of the attack helicopters, accounting for both asymmetric and conventional warfare capabilities, is even more uncertain.

6 According to the White Paper on Defence and the Armed Forces of the Republic of Bulgaria, 2010, p.27

7 According to the White Paper on Defence and the Armed Forces of the Republic of Bulgaria, 2010, pp. 28-29.

$8 \quad$ For this and other indicators see, for example, Todor Tagarev and Lidia Velkova, "Bulgaria's Defence Policy and Force Size from a Comparative Macro Perspective," Information \& Security: An International Journal 23:1 (2009): 115-128, <www.procon.bg/node/488>.

$9 \quad$ Approximately BGN 33000 ( EUR 16800 ) including reserve military personnel

10 Approximately BGN 37800 ( EUR 19 300) including reserve military personnel

11 Approximately BGN 42200 ( EUR 21530 ) including reserve military personnel

12 Approximately BGN 48282 ( EUR 24600 ) including reserve military personnel

13 Approximately BGN $56300(\sim$ EUR28 700) including reserve military personnel

14 Approximately BGN 64600 ( EUR 32 900) including reserve military personnel 
- Bulgarian Navy, which is of big importance to Bulgarian national security and Bulgaria's interests in the Adriatic and Caspian regions, is less and less likely to be able to keep "patching up" the situation with the second-hand ships at its disposal and without contemporary surface ships and U-boats. The acquisition of 4 contemporary corvettes, which was actually not accomplished, was to amount to more than BGN 1 bn. With the presence of numerous, potentially hostile navy forces in the Black Sea, the Bulgarian Navy can have a significant place in the national and collective defence and the protection of Bulgarian national interests in the region. ${ }^{15}$

- With the exception of improvements in terms of individual equipment and the controversial purchase of Mercedes transport vehicles, Bulgarian Land Forces have at their disposal combat vehicles from 1980s, which were designed in 1960s and 1970s. The overall rearmament, without which the Land Forces would not be able to reach similar capability level as Bulgaria's western allies, which in turn leads to inability to operate jointly with them, would again amount to more than BGN 2 bn. The Land Forces contribute the most to the current and future expedition operations of the Armed Forces, as well as to collective defence and maintaining stability in the region.

The implementation of those projects would require defence expenditure of $1.5-2 \%$ of GDP. The presented assumptions about the level of financing show that in case the scenario of a "Fixed budget (BGN 990630 mil)" is implemented, doubt is going to be cast over the overall concept of Armed Forces development. In that case, if funds for modernization are not allocated from the state budget on a regular basis, it would not be possible to maintain and develop the stipulated (reduced) structure of the forces. This means that, in a few years, we can expect another overall revision of the state's view on the place of armed forces among the tools of national politics.

15 For details see Georgi Tsvetkov, "Maritime Defence Investment Policy of the Republic of Bulgaria," Information \& Security: An International Journal 27:2 (2011): 163-147, <www.procon.bg/node/2497>. 